\title{
Analisis Postur Kerja Operator Las dengan Metode RULA : Studi kasus di UKM Las XYZ Karanganyar
}

\author{
Ainur Komariah*1, Fajar Dwi Prasetyo $^{2}$, dan Suprapto ${ }^{3}$ \\ 1,2Program Studi Teknik Industri, Universitas Veteran Bangun Nusantara, \\ Jl. Letjend Sujono Humardani No. 1, Sukoharjo, 57521. \\ e-mail: *1ainurkomariah @yahoo.com, ${ }^{2}$ fajardwiprasetyo61@gmail.com, \\ ${ }^{3}$ supraptodd@yahoo.com
}

(artikel diterima: 23-06-2020, artikel disetujui: 12-07-2020)

\begin{abstract}
Abstrak
Postur kerja operator dalam kegiatan produksi sangat penting untuk diperhatikan. Postur kerja yang ergonomis akan mendukung produktivitas kerja. Di UKM Las XYZ ada tiga postur kerja yang diadopsi oleh operator las yaitu berdiri membungkuk, duduk di kursi pendek, dan jongkok. Pekerjaan pengelasan adalah pekerjaan yang menimbulkan keluhan otot tertinggi dibanding pekerjaan lain di UKM ini. Tujuan penelitian ini adalah untuk menilai resiko postur kerja yang diadopsi operator las. Metode asesmen yang digunakan adalah Rappid User Limb Assesment (RULA) dan Nordic Body Map. Hasil penelitian menunjukkan bahwa skor akhir dari postur kerja berdiri membungkuk memiliki skor 7, yang berarti bahwa postur kerja ini perlu diinvestigasi dan diimplementasikan tindakan perbaikan. Postur kerja duduk di kursi pendek dan jongkok menghasilkan skor sebesar 6, yang berarti bahwa postur kerja ini perlu diinvestigasi lebih lanjut dan dilakukan perbaikan segera. Pengukuran keluhan otot menunjukkan bahwa bagian tubuh yang mengalami nyeri paling sakit adalah punggung dan pinggang, dengan rata-rata skor NBM sebesar 4 (sangat sakit). Hal ini disebabkan oleh postur kerja statis atau repetitif dengan frekuensi tinggi yang diadopsi oleh operator las.
\end{abstract}

Kata Kunci : postur kerja, operator las, RULA, NBM

\begin{abstract}
The operator's work posture in production activities is very important to note. Ergonomic work posture will support work productivity. In UKM Las XYZ there are three work postures adopted by the welding operator namely standing bent, sitting on a short chair, and squatting. Welding is the job that causes the highest muscle complaints compared to other jobs in this UKM. The purpose of this study was to assess the risk of work posture adopted by welding operators. The assessment method uses the Rapid User Limb Assessment (RULA) and the Nordic Body Map. The results showed that the final score of the work posture bent has a score of 7, which means that this work posture needs to be investigated and implemented corrective actions. Work postures sitting in short chair and squatting produce a score of 6 , which means that this work posture needs further investigation and immediate improvement. Measurement of muscle complaints showed that the part of the body that was experiencing the most pain was back and waist, with an average NBM score of 4 (very sick). This is caused by static or repetitive high frequency work postures adopted by the welding operator.
\end{abstract}

Keywords : work posture, welding operator, RULA, NBM

\section{PENDAHULUAN}

Dalam proses pengerjaan benda kerja yang menggunakan tenaga manusia, postur kerja operator sangat penting untuk diperhatikan. Postur kerja didefinisikan sebagai postur yang diadopsi oleh karyawan saat melakukan tugas kerja (Roman-liu, 2014). Postur kerja termasuk salah satu faktor ergonomi (McPhee et al., 2009). 
Penerapan prinsip ergonomi dalam dunia kerja, tak terkecuali postur kerja, berpengaruh pada peningkatan produktivitas, peningkatan kesehatan dan keselamatan pekerja, peningkatan kualitas pekerjaan, dan pada akhirnya berpengaruh pada peningkatan kepuasan dalam bekerja (Fernandez \& Goodman, 2000).

Sebaliknya, postur kerja yang canggung atau tidak ergonomis dapat menimbulkan masalah bagi pekerja. Postur kerja yang tidak ergonomis diartikan sebagai postur tubuh yang tidak biasa atau sulit dilakukan oleh tubuh. Hal itu menyebabkan stres pada otot dalam tubuh sehingga timbul rasa sakit yang menyebabkan kelelahan dan cedera (Hambali et al., 2019). Gangguan pada otot atau yang biasa disebut sebagai musculoskeletal disorders adalah cedera dan gangguan sistem muskuloskeletal, seperti carpal tunnel syndrome, sakit leher, dan sakit punggung. Gangguan otot ini sering disebabkan oleh postur kerja yang buruk (Schneck et al., 2019). Masalah kesehatan karena postur kerja tidak ergonomis sering terjadi pada pekerja di industri berat termasuk industri manufaktur perakitan mekanik (Hambali et al., 2019). Di Amerika Serikat, gangguan otot adalah kategori cedera di tempat kerja yang terbesar dan pengeluaran setiap tahun untuk perawatan kesehatan akibat cedera di tempat kerja telah lebih dari $\$ 90$ Miliar (Schneck et al., 2019)

Umumnya di negara berkembang, industri skala kecil banyak mempekerjakan orang sebagai pengganti otomatisasi (Ayub \& Shah, 2018), tak terkecuali di Indonesia. Pekerjaan yang dilakukan secara manual berpotensi menyebabkan cedera, yang salah satunya disebabkan oleh postur kerja dan pekerjaan yang berulang (Street et al., 2010).

Salah satu bidang industri kecil yang tumbuh di Indonesia adalah industri las. Bengkel las melayani pengelasan untuk konstruksi, pagar, teralis, dan sebagainya. Sebagian besar pekerjaan dilakukan secara manual. Dalam studi ini, penulis mengambil kasus di UKM Las XYZ yang terletak di Karanganyar Jawa Tengah.

Ada tiga macam pekerjaan utama yang dilakukan oleh operator, yaitu pemotongan pipa besi, penghalusan pipa besi, dan pengelasan. Observasi pendahuluan telah dilakukan. Operator diukur keluhan gangguan ototnya dengan instrumen Nordic Body Map (NBM). NBM merupakan instrumen yang umum digunakan untuk mengukur ketidaknyamanan atau nyeri pada bagian tubuh (Kroemer Elbert et al., 2018). Hasil observasi menunjukkan bahwa : (1) pekerjaan pemotongan pipa besi menghasilkan rerata skor NBM 62, yang berarti tingkat resiko sedang; (2) pekerjaan penghalusan pipa besi menghasilkan rerata skor NBM 46, yang berarti tingkat resiko rendah; dan (3) pekerjaan pengelasan menghasilkan rerata skor NBM sebesar 74, yang berarti tingkat resiko tinggi. Di antara tiga jenis pekerjaan, pengelasan merupakan pekerjaan dengan tingkat resiko paling tinggi.

Pada proses pengelasan, ada tiga postur kerja yang diadopsi oleh pekerja, yaitu (1) postur berdiri membungkuk; (2) postur duduk di kursi pendek, dan (3) postur jongkok. Dalam bekerja operator menggunakan satu atau dua postur kerja secara bergantian, yang dipertahankan selama durasi jam kerja, yaitu 8 jam sehari dengan 1 jam istirahat. Berdasarkan observasi dan wawancara pendahuluan yang telah dilakukan, pekerja sering kali merasakan keluhan sakit (nyeri) pada bagian tubuh tertentu. Nyeri dirasakan terutama di daerah leher, bahu, dan punggung. Keluhan nyeri ini cukup mengganggu aktivitas bekerja.

Hal inilah yang mendorong penulis untuk melaksanakan penelitian mengenai postur kerja pengelasan di UKM Las XYZ. Metode yang digunakan penulis untuk menginvestigasi postur kerja adalah metode Rapid Upper Limb Assesment (RULA). Metode ini menggunakan diagram dari postur tubuh dan 3 tabel skor dalam menetapkan evaluasi faktor resiko (McAtamney \& Nigel Corlett, 1993). Hasil dari 
penelitian ini adalah rekomendasi tindakan sehubungan dengan skor yang diperoleh dalam penilaian postur kerja.

\section{METODE PENELITIAN}

Objek penelitian adalah UKM Las XYZ Kabupaten Karanganyar, Provinsi Jawa Tengah. Bidang usahanya adalah jasa las. Subjek penelitian adalah para pekerja dengan jumlah 9 orang. Benda kerja yang dikerjakan pada saat observasi adalah pagar teralis, pintu, dan tangga. Kriteria dari subjek penelitian adalah laki-laki dengan usia 25 hingga 45 tahun, dalam kondisi sehat, tidak memiliki penyakit degeneratif, dan bersedia menjadi responden.

Peralatan utama yang digunakan adalah kamera, lembar kerja RULA, lembar pengamatan NBM, dan goniometer. Kamera berfungsi untuk mendokumentasikan gambar atau video operator yang bekerja menggunakan tiap-tiap postur kerja yang diadopsi. Lembar kerja RULA digunakan untuk menilai postur kerja ditinjau dari pergerakan leher, kaki, lengan atas, lengan bawah, pergelangan tangan, punggung, mengukur beban, dan kegiatan (Gambar 1). NBM digunakan untuk menilai skor keluhan otot yang diderita pekerja (Gambar 2). Keluhan nyeri diberi skor $1-4$. Skor 1 berarti tidak sakit, skor 2 berarti agak sakit, skor 3 berarti sakit, dan skor 4 berarti sangat sakit. Goniometer digunakan untuk mengukur sudut atau memungkinkan objek diputar ke posisi sudut yang tepat.

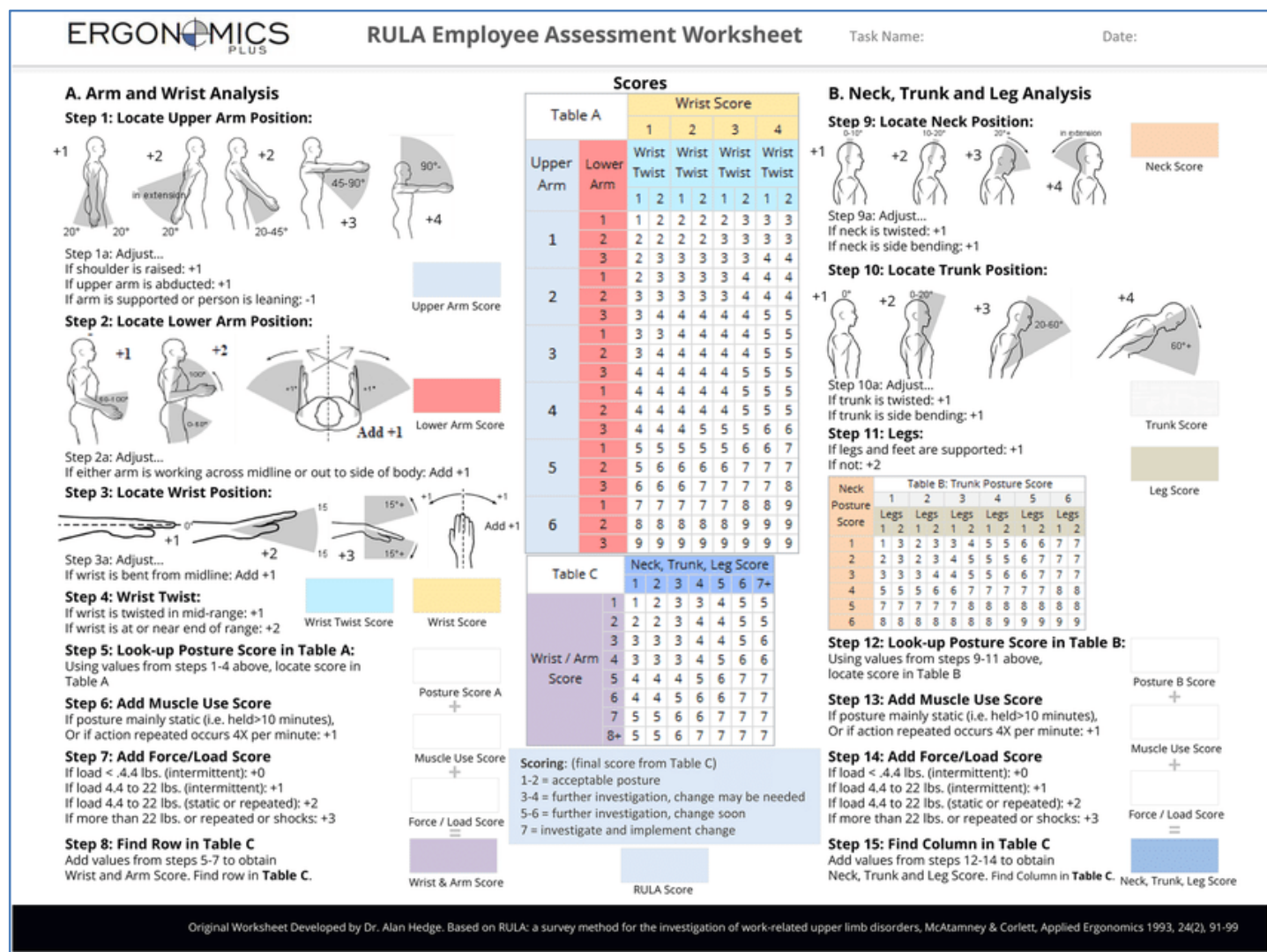

Gambar 1. Lembar kerja RULA (Wijsman et al., 2019) 


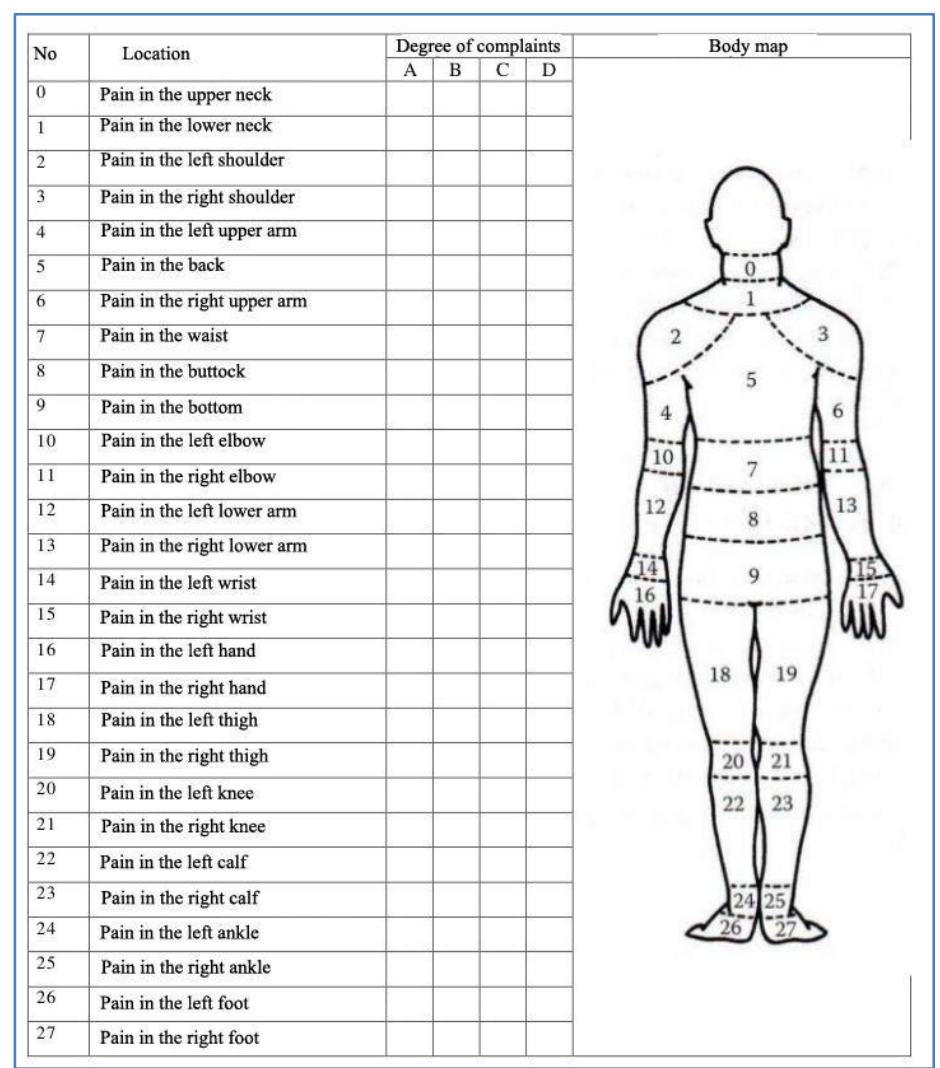

Gambar 2. Lembar pengamatan Nordic Body Map (Zadry et al., 2017)

Tahapan penelitian diawali dengan pengumpulan data yaitu : (1) data karakteristik postur kerja yang diteliti dari foto atau video, dan (2) Data keluhan otot operator pengelasan. Foto atau video postur kerja tersebut digunakan untuk mendapatkan data yang dibutuhkan dalam action level table RULA. Setelah itu dilakukan analisis dan dilanjutkan menghitung final score table. Dari hasil skor akhir, ditarik kesimpulan atas postur kerja yang diadopsi oleh pekerja.

\section{HASIL DAN PEMBAHASAN}

\section{Penilaian Postur Kerja}

Tiga postur kerja yang diadopsi oleh operator pengelasan adalah seperti yang terlihat dalam Gambar 3.

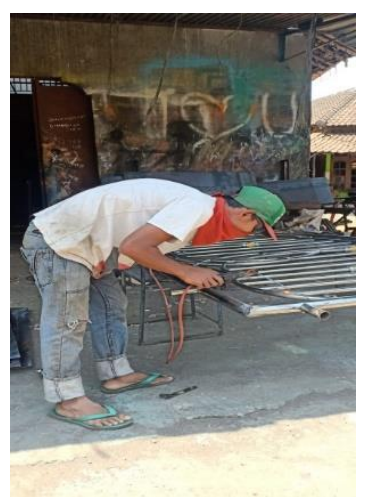

(a)

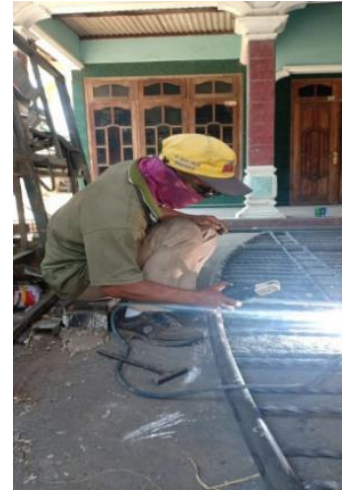

(b)

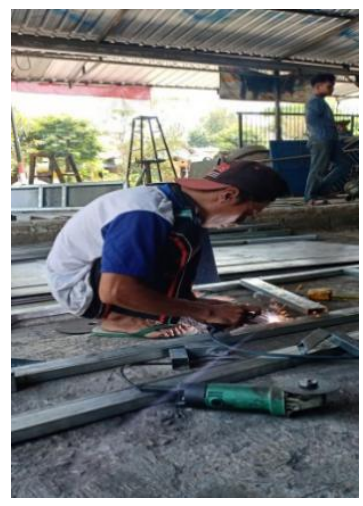

(c)

Gambar 3. Postur kerja (a) berdiri membungkuk;

(b) duduk di kursi pendek; (c) jongkok 
Dengan menggunakan pedoman RULA pada Gambar 1, dilakukan penilaian terhadap semua postur kerja. Sebagai contoh untuk postur berdiri membungkuk, penilaiannya adalah sebagai berikut :

1. Pergelangan tangan (wrist) memiliki sudut $15^{\circ}$, maka skor $=2$

2. Lengan atas (upper arm) membentuk sudut $45^{\circ}-90^{\circ}$, maka skor $=3$

3. Lengan bawah (lower arm) membentuk sudut $>100^{\circ}$, maka skor $=2$

4. Putaran pergelangan tangan (wrist twist) berada pada garis tengah, maka skor $=1$

5. Dicari skor dalam Gambar 2 (Table A) untuk postur berdiri membungkuk seperti yang dijelaskan dalam Tabel 1, diperoleh skor Tabel $\mathrm{A}=3$

6. Ditambah skor postur kerja statis, maka skor +1

7. Ditambah skor beban kerja. Berat alat las antara 4,4-22 lbs dan beban kerja intermitten, maka skor +1

8. Diperoleh skor total $=3+1+1=5$

Selanjutnya, dicari skor untuk Tabel B dengan langkah-langkah sebagai berikut:

1. Leher (neck) membentuk sudut $>20^{\circ}$, maka diberi skor $=3$

2. Punggung (trunk) membentuk sudut $>60^{\circ}$, maka diberi skor $=4$

3. Kaki (legs) seimbang karena dalam keadaan berdiri dengan berat terdistribusi dengan rata oleh kedua kaki, maka diberi skor $=1$

4. Dicari skor dalam Gambar 2 (Table B), diperoleh skor $=5$. Penentuan skor dijelaskan dalam Tabel 2.

5. Ditambah skor postur kerja statis, maka skor +1

6. Ditambah skor beban kerja. Berat alat las antara 4,4-22 lbs dan beban kerja intermitten, maka skor +1

7. Total skor Grup $B=5+1+1=7$

8. Dari skor Grup A dan Skor Grup B, dicari skor akhir dalam Table C. Diperoleh skor akhir $=7$. Penentuan skor akhir dijelaskan dalam Tabel 3.

Tabel 1. Skor Grup A RULA untuk postur berdiri membungkuk

\begin{tabular}{|c|c|c|c|c|c|c|c|c|c|}
\hline \multirow{4}{*}{$\begin{array}{c}\text { Upper } \\
\text { Arm }\end{array}$} & \multirow{4}{*}{$\begin{array}{c}\text { Lower } \\
\text { Arm }\end{array}$} & \multicolumn{8}{|c|}{ Wrist } \\
\hline & & \multicolumn{2}{|c|}{$\mathbf{1}$} & \multicolumn{2}{|c|}{2} & \multicolumn{2}{|c|}{3} & \multicolumn{2}{|c|}{4} \\
\hline & & \multicolumn{2}{|c|}{ Wrist Twist } & \multicolumn{2}{|c|}{ Wrist Twist } & \multicolumn{2}{|c|}{ Wrist Twist } & \multicolumn{2}{|c|}{ Wrist Twist } \\
\hline & & 1 & 2 & $\underline{1}$ & 2 & 1 & 2 & 1 & 2 \\
\hline \multirow{3}{*}{1} & 1 & 1 & 2 & 2 & 2 & 2 & 3 & 3 & 3 \\
\hline & 2 & 2 & 2 & 2 & 2 & 3 & 3 & 3 & 3 \\
\hline & 3 & 2 & 3 & 2 & 3 & 3 & 3 & 4 & 4 \\
\hline \multirow{3}{*}{2} & 1 & 2 & 2 & 2 & 3 & 3 & 3 & 4 & 4 \\
\hline & 2 & 2 & 2 & 2 & 3 & 3 & 3 & 4 & 4 \\
\hline & 3 & 2 & 3 & 3 & 3 & 3 & 4 & 4 & 5 \\
\hline \multirow{3}{*}{$\underline{\mathbf{3}}$} & 1 & 2 & 3 & 3 & 3 & 4 & 4 & 5 & 5 \\
\hline & $\underline{2}$ & 2 & 3 & $\underline{3}$ & 3 & 4 & 4 & 5 & 5 \\
\hline & $\overline{3}$ & 2 & 3 & $\overline{3}$ & 4 & 4 & 4 & 5 & 5 \\
\hline
\end{tabular}

*) Skor ditunjukkan dengan sel yang diarsir dan angka yang bergaris bawah 
Tabel 2. Skor Grup B RULA untuk postur berdiri membungkuk

\begin{tabular}{cccccccccc}
\hline & \multicolumn{8}{c}{ Trunk } \\
\cline { 2 - 10 } Neck & & $\mathbf{1}$ & \multicolumn{1}{c}{$\mathbf{2}$} & \multicolumn{3}{c}{$\mathbf{3}$} & \multicolumn{4}{|c}{} \\
\cline { 2 - 10 } & Legs & Legs & Legs & Legs & Legs & Legs & Legs & Legs \\
\cline { 2 - 9 } & $\mathbf{1}$ & $\mathbf{2}$ & $\mathbf{1}$ & $\mathbf{2}$ & $\mathbf{1}$ & $\mathbf{2}$ & $\mathbf{1}$ & $\mathbf{2}$ \\
\hline 1 & 1 & 3 & 2 & 3 & 3 & 4 & 5 & 5 \\
2 & 2 & 3 & 2 & 3 & 4 & 5 & 5 & 5 \\
$\mathbf{3}$ & 3 & 3 & 3 & 4 & 4 & 5 & $\mathbf{5}$ & 6 \\
4 & 5 & 5 & 5 & 6 & 6 & 7 & 7 & 7 \\
\hline
\end{tabular}

*) Skor ditunjukkan dengan sel yang diarsir dan angka yang bergaris bawah

Tabel 3. Skor Grup C RULA untuk postur berdiri membungkuk

\begin{tabular}{cccccccc}
\hline \multicolumn{7}{c}{ Score Group B } \\
\hline Score Group A & $\mathbf{1}$ & $\mathbf{2}$ & $\mathbf{3}$ & $\mathbf{4}$ & $\mathbf{5}$ & $\mathbf{6}$ & $\mathbf{7 +}$ \\
\hline 1 & 1 & 2 & 3 & 3 & 4 & 5 & 5 \\
2 & 2 & 2 & 3 & 4 & 4 & 5 & 5 \\
3 & 3 & 3 & 3 & 4 & 5 & 5 & 6 \\
4 & 3 & 3 & 3 & 4 & 5 & 6 & 6 \\
$\mathbf{5}$ & 4 & 4 & 4 & 5 & 6 & 7 & $\underline{\mathbf{7}}$ \\
6 & 4 & 4 & 5 & 6 & 6 & 7 & 7 \\
7 & 5 & 5 & 6 & 6 & 7 & 7 & 7 \\
8 & 5 & 5 & 6 & 7 & 7 & 7 & 7 \\
\hline
\end{tabular}

*) Skor ditunjukkan dengan sel yang diarsir dan angka yang bergaris bawah

Hasil penilaian postur kerja untuk postur duduk di kursi pendak dan jongkok, dirangkum dalam Tabel 4.

Tabel 4. Skor Tabel Rula A untuk postur kerja duduk dan jongkok

\begin{tabular}{|c|c|c|c|c|c|}
\hline No & Postur Kerja & Deskripsi postur & $\begin{array}{c}\text { Skor } \\
\text { A }\end{array}$ & $\begin{array}{c}\text { Skor } \\
\text { B }\end{array}$ & $\begin{array}{l}\text { Skor } \\
\text { Akhil }\end{array}$ \\
\hline 1 & $\begin{array}{l}\text { Duduk di kursi } \\
\text { pendek }\end{array}$ & $\begin{array}{l}\text { Wrist } 15^{0}, \text { skor }=2 \\
\text { Upper arm } 20^{\circ}, \text { skor }=1 \\
\text { Lower arm } 60^{0}-100^{\circ}, \text { skor }=1 \\
\text { Wrist twist pada garis tengah, skor }=1 \\
\text { Postur kerja statis, skor }+1 \\
\text { Berat alat las antara } 4,4-22 \mathrm{lbs} \text { dan } \\
\text { beban kerja intermitten, skor }+1\end{array}$ & 4 & 7 & 6 \\
\hline & & Neck $10^{0}-20^{\circ}$, skor $=2$ & & & \\
\hline & & $\begin{array}{l}\text { Trunk, } 20^{\circ}-60^{\circ} \text {, dengan skor }=3 \\
\text { Legs, tidak tertopang, skor }=2 \\
\text { Postur kerja statis, skor }+1 \\
\text { Berat alat las antara } 4,4-22 \mathrm{lbs} \text { dan } \\
\text { beban kerja intermitten, skor }+1\end{array}$ & & & \\
\hline 2 & Jongkok & $\begin{array}{l}\text { Wrist } 0^{0}-15^{0}, \text { skor }=2 \\
\text { Upper arm } 20^{0}-45^{0}, \text { skor }=2 \\
\text { Lower arm } 60^{0}-100^{0} \text {, skor }=1 \\
\text { Wrist twist pada garis tengah, skor }=1 \\
\text { Postur kerja statis, skor }+1 \\
\text { Berat alat las antara } 4,4-22 \text { lbs dan } \\
\text { beban kerja intermitten, skor }+1\end{array}$ & 4 & 6 & 6 \\
\hline
\end{tabular}




\begin{tabular}{llcccc}
\hline \multirow{2}{*}{ No } & \multirow{2}{*}{ Postur Kerja } & \multirow{2}{*}{ Deskripsi postur } & Skor & Skor & Skor \\
& & A & B & Akhir \\
\hline
\end{tabular}

Neck $>20^{\circ}$, skor $=3$

Trunk, $20^{\circ}-60^{\circ}$, dengan skor $=3$

Legs, tertopang, skor $=1$

Postur kerja statis, skor +1

Berat alat las antara 4,4-22 lbs dan

beban kerja intermitten, skor +1

Selanjutnya, berdasarkan skor akhir yang diperoleh, ditarik kesimpulan mengenai postur kerja, sesuai dengan pedoman RULA di Gambar 1. Hasil penilaian untuk tiap postur kerja tertera dalam Tabel 5.

Tabel 5. Hasil penilaian postur kerja dengan metode RULA

\begin{tabular}{clccl}
\hline No & Postur kerja & $\begin{array}{c}\text { Skor } \\
\text { akhir }\end{array}$ & $\begin{array}{c}\text { Level } \\
\text { resiko }\end{array}$ & \multicolumn{1}{c}{ Tindakan perbaikan } \\
\hline 1. & $\begin{array}{l}\text { Berdiri } \\
\text { membungkuk }\end{array}$ & 7 & Tinggi & $\begin{array}{l}\text { Lakukan investigasi, dan } \\
\text { implementasikan perubahan }\end{array}$ \\
2. & $\begin{array}{l}\text { Duduk di kursi } \\
\text { pendek }\end{array}$ & 6 & Sedang & $\begin{array}{l}\text { Perlu investigasi lebih lanjut, perubahan } \\
\text { segera } \\
\text { Perlu investigasi lebih lanjut, perubahan } \\
\text { segera }\end{array}$ \\
3. Jongkok & 6 & Sedang & \\
\hline
\end{tabular}

\section{Keluhan Muskuloskeletal}

Pengukuran keluhan muskuleskeletal dilakukan terhadap 3 operator, dengan hasil seperti yang tertera pada Tabel 6.

Tabel 6. Keluhan Muskuloskeletal pada Operator Las

\begin{tabular}{clcclc}
\hline No & Otot Skeletal & $\begin{array}{c}\text { Rerata } \\
\text { Skor }\end{array}$ & No & \multicolumn{1}{c}{ Otot Skeletal } & $\begin{array}{c}\text { Rerata } \\
\text { Skor }\end{array}$ \\
\hline 1 & Leher atas & 3,00 & 15 & Pergelangan tangan kiri & 2,33 \\
2 & Leher bawah & 3,00 & 16 & Pergelangan tangan kanan & 2,00 \\
3 & Bahu kiri & 2,00 & 17 & Tangan kiri & 3,00 \\
4 & Bahu kanan & 2,00 & 18 & Tangan kanan & 3,33 \\
5 & Lengan kiri atas & 3,67 & 19 & Paha kiri & 2,67 \\
6 & Punggung & 4,00 & 20 & Pahan kanan & 2,67 \\
7 & Lengan kanan atas & 3,67 & 21 & Lutut kiri & 2,67 \\
8 & Pinggang & 4,00 & 22 & Lutut kanan & 2,33 \\
9 & Pinggul & 2,00 & 23 & Betis kiri & 1,67 \\
10 & Pantat & 2,00 & 24 & Betis kanan & 1,67 \\
11 & Siku kiri & 1,67 & 25 & Pergelangan kaki kiri & 1,67 \\
12 & Siku kanan & 1,67 & 26 & Pergelangan kaki kanan & 1,67 \\
13 & Lengan kiri bawah & 2,67 & 27 & Kaki kiri & 3,67 \\
14 & Lengan kanan bawah & 3,33 & 28 & Kaki kanan & 3,67 \\
\hline
\end{tabular}




\section{Analisis}

Dari hasil asesmen tiga postur kerja operator pengelasan (berdiri membungkuk, duduk di kursi pendek, dan jongkok), diketahui ketiga postur kerja memiliki skor yang tinggi, yaitu $6-7$. Hal ini menunjukkan bahwa postur kerja yang diadopsi oleh operator las mengandung resiko cedera.

Postur berdiri membungkuk adalah postur kerja yang memiliki resiko paling tinggi (skor 7). Hasil ini selaras dengan hasil penelitian Nur et al. (2016), Gangopadhyay et al. (2010), dan Kusnandar \& Noya (2013) bahwa postur kerja berdiri membungkuk memiliki resiko tinggi dan berbahaya bagi sistem muskuloskeletal. Rekomendasi untuk postur kerja ini adalah segera dilakukan perbaikan.

Postur kerja duduk di kursi pendek juga memiliki resiko tinggi (skor 6). Hasil ini selaras dengan hasil penelitian Istighfaniar and Mulyono (2017) yang melaksanakan penelitian postur kerja pengasah batu dengan postur duduk di kursi pendek. Postur kerja tersebut menghasilkan skor akhir sebesar 7 dan termasuk dalam resiko level tinggi.

Postur kerja jongkok memiliki skor resiko sebesar 6. Hasil ini selaras dengan hasil penelitian Rinawati \& Romadona (2016) yang meneliti postur kerja operator pemilahan dan penimbangan laundry di RS, bahwa postur kerja kaki ditekuk jongkok memiliki tingkat resiko yang tinggi.

Dari data keluhan muskuloskeletal, dapat diketahui bahwa bagian tubuh yang mengalami nyeri otot paling parah adalah punggung dan pinggang. Hal ini dapat disebabkan oleh postur kerja statis yang diadopsi oleh operator. Menurut Tarwaka (Evadarianto, 2017) jika otot menerima beban statis secara terus menerus dan repetitif akan menimbulkan keluhan berupa kerusakan pada otot tendon, ligamen, dan sendi. Untuk itu, sesuai dengan rekomendasi RULA postur kerja operator pengelasan ini perlu segera di perbaiki.

\section{KESIMPULAN}

Berdasarkan hasil penelitian dapat disimpulkan bahwa postur kerja operator las yaitu berdiri membungkuk memiliki skor RULA paling tinggi yaitu 7 yang berarti bahwa postur kerja ini harus diinvestigasi dan diimplementasikan tindakan perbaikan. Postur kerja duduk di kursi pendek dan jongkok memiliki skor RULA sebesar 6, yang berarti bahwa postur ini memerlukan investigasi lebih jauh dan memerlukan perubahan segera.

\section{DAFTAR PUSTAKA}

Ayub, Y., \& Shah, Z. A. (2018). Assessment of Work Related Musculoskeletal Disorders in Manufacturing Industry. Journal of Ergonomics, 08(03). https://doi.org/10.4172/2165-7556.1000233

Evadarianto, N. (2017). Postur Kerja Dengan Keluhan Musculoskeletal Disorders Pada Pekerja Manual Handlingbagian Rolling Mill. The Indonesian Journal of Occupational Safety and Health, 6(1), 97. https://doi.org/10.20473/ ijosh.v6i1.2017.97-106

Fernandez, J. E., \& Goodman, M. (2000). Ergonomics in the Workplace. Exponent Health Group, 229-235. http://www.seas.columbia.edu/earth/wtert/sofos/ nawtec/nawtec08/nawtec08-0019.pdf

Gangopadhyay, S., Ghosh, T., Das, T., Ghoshal, G., \& Das, B. (2010). Effect of 
working posture on occurrence of musculoskeletal disorders among the sand core making workers of West Bengal. Central European Journal of Public Health, 18(1), 38-42. https://doi.org/10.21101/cejph.a3503

Hambali, R. H., Rahim, S. A. A., Azizan, N., Zali, Z., Akmal, S., \& Zin, M. H. (2019). Analysis the Awkward Posture Ergonomic Risk and Workstation Improvement Simulation in Mechanical Assembly Manufacturing Industry using DelmiaV5. IOP Conference Series: Materials Science and Engineering, 705(1), 0-6. https://doi.org/10.1088/1757-899X/705/1/012044

Istighfaniar, K., \& Mulyono, M. (2017). Evaluasi Postur Kerja Dan Keluhan Muskoloskeletal Pada Pekerja Instalasi Farmasi. The Indonesian Journal of Occupational Safety and Health, 5(1), 81. https://doi.org/ 10.20473/ijosh.v5i1.2016.81-90

Kroemer Elbert, K. E., Kroemer, H. B., \& Kroemer Hoffman, A. D. (2018). Introducing Ergonomics and Human Factors Engineering. In Ergonomics. https://doi.org/10.1016/b978-0-12-813296-8.00024-4

Kusnandar, Y., \& Noya, S. (2013). Working Posture Analysis and Design Using Rula ( Rapid Upper Limb Assessment ) Method in Production Process At Pt . Indana Paint. Jurnal Ilmiah Teknik Industri, 12(2), 111-125. https://webcache. googleusercontent.com/search?q=cache:TtNo_7Lpa_UJ:https://pdfs.semanticsc holar.org/fc59/ac25b7ae83b7e4fce8f7f9652f2db48af1a6.pdf $+\& c d=6 \& h l=e n \& c t$ $=\mathrm{clnk} \& \mathrm{gl}=\mathrm{my}$

McAtamney, L., \& Nigel Corlett, E. (1993). RULA: a survey method for the investigation of work-related upper limb disorders. Applied Ergonomics, 24(2), 91-99. https://doi.org/10.1016/0003-6870(93)90080-S

McPhee, B., Scott, P., \& Kogi, K. (2009). Ergonomics Guidelines for occupational health practice in industrially developing countries. http://www.icohweb.org/ site_new/multimedia/news/pdf/ERGONOMICS GUIDELINES Low res Final April 2010.pdf

Nur, R. F., Lestari, E. R., \& Mustaniroh, S. A. (2016). Analisis Postur Kerja pada Stasiun Pemanenan Tebu dengan Metode OWAS dan REBA, Studi Kasus di PG Kebon Agung, Malang. Teknologi Dan Manajemen Agroindustri, 5(1), 39-45.

Rinawati, S., \& Romadona. (2016). Analisis Risiko Postur Kerja Pada Pekerja Di Bagian Pemilahan Dan Penimbangan Linen Kotor Rs. X. Journal of Industrial Hygiene and Occupational Health, 1(1), 39. https://doi.org/ 10.21111/jihoh.v1i1.604

Roman-liu, D. (2014). Risk factors for musculoskeletal disorders - working postures (pp. 2-11). https://oshwiki.eu/wiki/Risk_factors_for_musculoskeletal _disorders____working_postures

Schneck, A., Liu, S., \& Lee, A. (2019). Posture Wellness Solutions in the Workplace: A Current Review. Journal of Ergonomics, 09(03), 1-5. https://doi.org/10.35248/ 2165-7556.19.9.252

Street, S., Ave, G., Wa, C., House, M., Street, P., \& Wa, E. P. (2010). Prevention of musculoskeletal disorders from performing manual tasks in mining workplaces (Issue March).

Wijsman, P. J. M., Molenaar, L., van't Hullenaar, C. D. P., van Vugt, B. S. T., Bleeker, W. A., Draaisma, W. A., \& Broeders, I. A. M. J. (2019). Ergonomics in handheld and robot-assisted camera control: a randomized controlled trial. Surgical Endoscopy, 33(12), 3919-3925. https://doi.org/10.1007/s00464-019-06678-1

Zadry, H. R., Fithri, P., Triyanti, U., \& Meilani, D. (2017). An ergonomic evaluation of mountaineering backpacks. ARPN Journal of Engineering and Applied Sciences, 12(18), 5333-5338. 